\title{
CONTESTATIONS AND CONFLICTING LIFEWORLDS IN CONSERVATION FARMING PRACTICES IN ZIMBABWE: THE EXPERIENCES OF PEASANT SMALLHOLDER FARMERS IN CHIVI SOUTH DISTRICT IN MASVINGO
}

\author{
L. Nhodo, S. Gukurume, O. Mafongoya, Lecturers \\ Department of Sociology and Social Anthropology, Great Zimbabwe University, Zimbabwe \\ E-mail: lloyd.nhodo@gmail.com
}

\begin{abstract}
This study builds on an earlier research done by the researchers in Chivi south district on the impact of conservation farming on food security. The major focus of this study however is on the conflicts and contradictions embedded in conservation farming owing to differential perceptions and life-worlds and implications thereof on sustainable agriculture. It contends that these diverging and conflicting life-words are counter-productive and inimical to the goal of sustainable development in general and sustainable agriculture in particular. The treatise argues that unless and until an interface analysis is implemented to try and sever the impasse, conservation farming just like the preceding farming intervention programs proffered by the state and non-state state actors as the panacea to the incessant food insecurity quagmires bedeviling perennially drought prone regions, will be rendered obsolete. Findings in this study reveal that the conservation farming project is shrouded in perpetual conflicts and struggles pitting several stakeholders involved in the program. The study was grounded in qualitative methodology and adopted unstructured interviews, focus group discussions (FGDs) and expert interviews as the main data gathering techniques. Norman Long's Actor Oriented Approach (AOA) was the theoretical lens used in the research as the major analytical framework to understand and bridge the impasse for conservation farming to have meaning to the stakeholders and leave up to its hype in rural development.
\end{abstract}

\section{KEY WORDS}

Agriculture; Sustainable development; Sustainable agriculture; Interface.

A number of Sub-Saharan countries are confronted by a myriad of agricultural sustainability challenges due to a multiplicity of factors that militate against agricultural productivity. Chief among them is the fact that they constitute a hydro - climatic region subject to extreme rainfall variability and water scarcity and thus the region and particularly Zimbabwe has been dogged by perpetual food shortages. Non-governmental organizations have played a significant role in the development of rural communities and subsequent poverty alleviation in these areas. In the wake of this agricultural catastrophe, local and International non - governmental organizations have devised strategies to ameliorate such challenges and enhance food security in the region. To this end, conservation farming has been widely embraced by NGOs as the ideal farming practice to deal with Africa's agricultural productivity problems. Conservation farming is generally defined as any tillage sequence with the objective of minimizing or reducing the loss of soil and water, operationally a tillage or tillage and planting combination which aims to leave a permanent mulch or crop cover on the surface. Bwalya (1999) argues that conservation farming entails those tillage practices where by minimum or no disturbance is done on the soil for the purposes of crop production. It involves the making of furrows or holes where seed is planted. The rest of the field remains undisturbed and crop residue is left on the surface. What should be stressed is the argument that this practice reduces soil erosion, causes build up of organic matter in the soil, hence better chemical and physical soil fertility. Kassam (2009) notes that conservation farming has been practiced for over three decades now and has consequently spread widely across the globe.

In line with the aforementioned argument, proponents of conservation farming stress that this farming practice is critically important in Africa due to its agricultural and 
environmental benefits ${ }^{1}$.According to Hove \&Twomlow (2006) the initial basin tillage concept was developed by Oldrieve in Zimbabwe in the late 1980s. It was then subsequently modified and promoted by the Zimbabwean Conservation Agricultural Task force for Southern Zimbabwe convened by $\mathrm{FAO}^{2}$. In Zimbabwe conservation farming programs are championed and supported by the United Kingdom's Department for International Development (DFID) Protracted Relief Program and the European Commission Humanitarian Aid Office (ECHO). Kaumbutho \& Kienzle (2008) and Lahmar (2009) argued that improved agricultural productivity using conservation farming systems based on non - inversion tillage methods, have predominantly originated from farming systems in sub - humid and humid regions where water is not a key limiting factor for crop growth. However, it should be noted that the adoption of this farming practice in Zimbabwe has been lethargic, albeit relentless encouragement by NGOs to embrace conservation farming and implement it (Gukurume, Nhodo \& Dube, 2010; Growing \& Palmer, 2008;Fowler \& Rockstrom, 2001).Despite the fact that conservation farming principles emphasize 'community' involvement, many village farmers have raised a number of questions pertaining to the feasibility of this farming practice in their respective communities. Villagers have dismissed NGOs for taking a traditional top down approach to most of their rural development programmes and particularly conservation farming, oblivious of the contestations and conflicting life-worlds typical of any society. This has tended to militate against the success of many programmes. Gukurume, Nhodo \& Dube (2010) contend that NGOs dealing with the conservation farming program in Zimbabwe and particularly Chivi have tended to gloss over critical issues pertaining to the shear heterogeneity characteristic of many communities. Infact these NGOs have tended to view the 'community' as a homogeneous totality, as a result contestations have become ubiquitous in societies composed of varied worldviews. To this end, conservation farming programmes have faced relentless resistance from some sections of the 'community', citing lack of consultation by NGOs, imposition of ideas on them and consequently undermining the knowledge systems of the local people. Accordingly the local 'community' has failed to identify with the program labeling it as "their" program not "our" program due to the imposition of certain prescriptions (Gukurume, Nhodo \& Dube, 2010).

The researchers observed that while conservation farming is a noble program that can yield positive outcomes for the communities concerned, its success has been curtailed by the contestations between the various stakeholders involved in the project. According to Kassam (2009) and Landers (2007) conservation farming represents a fundamental change in production system thinking and constitutes practices that can make a major contribution to sustainable production and improvement in crop yields. It should be noted that following protracted bouts of food security catastrophe, several NGOs have prescribed new farming methods ideal for drought prone communities as a panacea to declining yields. However, despite advocating more of participatory involvement of villagers, some of these programmes have not been easily accepted. Conservation agriculture holds special promise for Africa, where farming communities face the problems of low yields, impoverished soils, lack of capital, and labour shortages brought on by the scourge of AIDS $^{3}$. It is a way to improve the livelihoods of millions of people and achieve sustainable agriculture over a wide area. It should however be noted that conservation farming prescriptions were largely developed and tested in researcher-managed trials, with only limited consideration of the problems and priorities of smallholder farmers for whom they were intended (Anderson, 1992; Ryan \& Spencer, 2001; Stoop \& Kassam, 2005; Hove \&Twomlow ,2006; Freidrich \& Kassam,2009) . Such a scenario has led to ambivalent outcomes of conservation farming depending on the area in question.

In Zimbabwe conservation farming is being promoted as a potential solution to the production problems facing smallholder farming families (FAO, 2008; Hobbs, 2007; Simuyemba, 1998; Shaxson, 2006). Nevertheless, Gukurume et al (2010) assert that

\footnotetext{
${ }^{1}$ A more detailed discussion on the CA concept and emerging global definitions can be found on the FAO web site at http://www.fao.org/ag/ca/

${ }^{2}$ See Conservation Tillage Implements for Smallholder Farming Systems

${ }^{3}$ HIV and AIDS has negatively impacted on the agricultural sector and conservation farming which requires labour, see the Human Development Report 2003.
} 
conservation farming can be extremely difficult for many villagers to accept because it goes against many of the villagers' cherished beliefs, for example villagers have questioned how crops can be grown without ploughing the land. It is against this background that the phenomenon of community participation becomes ideal for the success of the program. This is because it is important to realize that there are important socio-cultural issues involved in any major change of practices within the community. To this end, lack of villagers' participation will inevitably yield catastrophic results for the program since the success of any project largely rests on the involvement and support of the villagers in question ${ }^{4}$. Despite nearly two decades of development and promotion by the national extension program and numerous projects, adoption of conservation farming in Zimbabwe has been extremely low in the smallholder sector (Hobbes, 2007; Damrosch, 2008;Uphoff \& Kassam, 2009; Mazvimavi \& Twomlow,2008).Critics of the conservation farming program have noted that the project has only succeeded in fostering and entrenching a dependency syndrome on the villagers who are always anticipating free inputs from the NGOs advocating conservation farming.. Taking an Actor oriented approach to rural development this study sought to examine the contestations embedded in Conservation farming practices in Chivi south district, simultaneously evaluating the implications of these contestations on the overall success of conservation farming.

\section{STATEMENT OF THE PROBLEM}

The conservation farming program has been embroiled in protracted controversy and contestations as various stakeholders compete to assert their lifeworlds on other stakeholders. Thus, the conservation farming program has become a battlefield for competing knowledge systems and conflicting interests. Such conflicting lifeworlds have had dire ramifications on the overall success of the program. It has been observed that this program has largely been top - down in nature with dominant stakeholder imposing their ideas and decisions on the poor villagers. Such an approach has marred the realization of the intended goals and objectives of the intervention. It has been observed that most NGOs involved in the conservation farming program have erroneously assumed that the "community" is a homogeneous totality with uniform interests .This is however in sharp contrast to the nature of communities which are characterised by sheer heterogeneity and conflicting lifeworlds. That belief has led these NGOs into believing that what is good for one group is good for the whole "community". This generalization has impacted negatively on the success of the program as villagers felt that the program is an imposition meant to cater for the interests of the elite, pushing this farming enterprise into a political arena. What cannot be overlooked is the fact that researchers and exponents of conservation farming have overemphasized the technical side of conservation farming in relation to increased output thereby glossing over the socio-political dynamics of the said program and their implications on the success of the program.

\section{OBJECTIVES OF THE STUDY}

This study had two main objectives: to examine the contestations embedded in Conservation farming practices in Chivi south district, and to evaluate the implications of these contestations on the success of conservation farming.

\section{CONCEPTUAL FRAMEWORK}

This study adopted Norman Long's Interface analysis as its analytical lens in understanding the intricacy of the relationships between the competing interests of the NGOs, local authorities, ordinary villagers, politicians and extension workers involved in

\footnotetext{
${ }^{4}$ Conservation farming is best achieved through community driven development processes whereby local communities and villagers identify and implement the best options for conservation farming in their location
} 
conservation farming. Interfaces typically occur at points where different and often conflicting life-worlds intersect in social situations or arenas in which such interactions become oriented around problems of bridging ,accommodating, segregating or contesting social and cognitive standpoints(Long, 1992).Negotiations at the interface are normally carried out by individuals representing particular interest groups and in this study the bone of contention is over the ownership and control of the conservation farming technology. The NGOs marshaling conservation farming in Chivi south district claim to be the bona fide owners of the program by virtue of their ownership of material resources, which they are concomitantly translating into knowledge and power. The local authorities working in cahoots with the extension workers are simultaneously claiming a stake in conservation farming with the aim of achieving personal gains at the same time meeting their political agenda as well as that of the former ruling party ZANU PF. Local farmers have refused to be left out in the conservation farming debacle, they believe that they should be the real owners of the program rather than relying on outside knowledge and expertise. What is also at stake is the clash over the primacy of knowledge. While the NGOs through modern scientific knowledge are trying to create hegemony over local knowledge, the local farmers are embarking on counter hegemonic struggles whereby they are trying to affirm and re-affirm the dominance of indigenous knowledge systems. This clash of interests has thus brought an impasse on conservation farming. The analytical insight in question was important in conveying the idea of contested arenas in which actors' understandings, interests and values are pitched against each other (Long, 1992).In this scenario it thus became imperative to counterpoise the voices, grievances, experiences and practices of all relevant social actors involved in the conservation farming practice. The concept of "Interface" helps in understanding the transformation, production and reproduction of differences in worldviews or cultural paradigms since interface situations often provide a means by which individuals or groups come to define their own cultural and ideological positions vis a' vis those espousing or typifying opposing views.

\section{METHODOLOGY}

This study was grounded in qualitative research methodology, with unstructured interviews, focus group discussions, transect walks, key informant interviews and secondary sources of data being utilized as the main data soliciting techniques. Qualitative methodology was ideal in capturing the perceptions of various stakeholders involved in the conservation farming program. Qualitative methodology also enabled the study to capture the multivocality and complex nature of the contestations surrounding conservation farming.

Data Collection Techniques. Unstructured interviews were used as the main method of data collection, and they enabled the gaining of in-depth insights into the politics surrounding the conservation farming program in Chivi. Interviews ranged from informal conversational interviews to unstructured formal interviews as well as key informant interviews. Unstructured interviews were also employed because of their appropriateness in the case study method adopted in this research. They provided room for the researcher to probe deeply into the issue of conservation farming and the lifeworlds of various stakeholders involved in the program. Key informant interviews were held with some local authorities and village farmers, extension workers and NGO officials operating in Chivi. Key informant interviews helped in capturing the multi - perceptions of various stakeholders and reconciling their conflicting perceptions. There was also extensive use of secondary sources of information in this study and this helped in augmenting and corroborating data gathered through other methods. Focus group discussions augmented interviews in soliciting information in this study. Transect walks in this study offered observational insights into the practical activities of conservations farming and how the villagers have responded to some of the prescriptions of conservation farming. 


\section{PRESENTATION AND DISCUSSION OF RESEARCH FINDINGS}

In spite of the intrinsic worth of conservation farming vaunted by the exponents of this farming method as a catalyst for sustainable agriculture, very little if any has been done to try and look into the impediments that come with the method in practice. Such drawbacks have inevitably led to the lethargic approach in the uptake of the said farming method in communal areas where it is being implemented by NGOs in Zimbabwe, to cushion the farmers against the detrimental effects of unfriendly climatic conditions. This observation is in tandem with the general observations made by Makwara (2010) who acknowledged that in spite of the conservation agriculture hype, an insignificant number of farmers in rural Zimbabwe have embraced conservation farming. This therefore lends credence to the desire to look into the practical challenges, that is contestations, conflict and contradictions that come with the adoption of the farming method particularly in rural areas such as Chivi.

From the outset we argue that all developmental intervention programmes are political, thus they are replete with conflict and contradictions over the meaning and purpose of such programmes to the stakeholder involved or their intended beneficiaries. This position is premised on our conviction that inasmuch as they belong to the same "community", people are different with regards to feelings, perceptions, attitudes and interests hence contradictions and conflict is ubiquitous. Of note however is the view that NGOs spearheading conservation farming are inadvertently balkanizing the residence of Chivi South as a homogeneous entity, whereas as observed these differential social actors have different and often conflicting interests and perceptions (life Wolds) toward conservation farming as a livelihood strategy that is aimed at pushing them out of the vicious cycle of poverty that they are currently entangled in. These conflicting and contradicting interests are overlapping, corresponding or conflicting each other. Hence there is need to pursue this heterogeneity in order to accommodate the interests of major stakeholders involved, for conservation farming to have meaning for its beneficiary at the same time meeting the goal of sustainable development. (See, Khamphorst etal 2009) Ironically NGOs in Chivi south either by default or by design have glossed over such an important element in rural development. They are blatantly reverting to orthodox developmental model or a top down approach to development camouflaging under the veil of participatory development. Paradoxically findings made in this study reveal that there is very little consultation being done with regards to the planning and implementation of this farming method. Such a retrogressive approach is undoubtedly having negative ramifications on the overall success of the whole project because to be successful any developmental intervention program ought to be designed and executed with significant participation from the grassroots, (Gukurume, Nhodo \& Dube, 2010) as opposed to "Cosmetic" participation as observed in Chivi south.

It is of paramount importance to note that the ideals of participatory development help to foster a genuine paradigm shift in development circles from a position where locals are perceived as sponges of development to a position where they are viewed as knowledgeable actors with different life-worlds and endowed with the capacity to calculate the means to an end of development. This is also in keeping with Long's (1992) Actor Oriented Approach in which he vehemently argued for a people centered development, to at least ameliorate the conflicts and contradictions deeply entrenched in intervention programmes like Conservation farming. Given the volatility of the situation in Chivi south Long (1992) henceforth believes that an interface analysis is a precondition for remedying the situation at hand. An interface occurs at points where different, conflicting life-worlds or social fields occur or more concretely in situations or arenas in which interventions become oriented around problems of bridging, accommodating, segregating, or contesting social evaluative and cognitive standpoints towards any developmental intervention program. (See Long 1992).

Taking the aforementioned theoretical lens as its axis the treatise identified a number of social actors involved in conservation farming with different Life-worlds which ought to be reconciled for conservation farming to achieve its projected objectives for its intended beneficiaries.

The NGOs advocating Conservation Farming in Chivi. In this study it was observed that the NGOs spearheading conservation farming in Chivi south, that is Action faim and Care 
International have a vested interest in the continuity and sustainability of the farming practice in question. This is primarily because they want to mollify the donor community by unorthodoxly portraying an optimistic picture about conservation farming so as to continue receiving the much needed funding. It was observed that these missionaries are so desperate to see the 'success' of the project at all costs. To buttress this position some employees of these NGOs who spoke on condition of anonymity revealed that the NGOs in question thrive on the art of hoodwinking the donor with the aim of presenting conservation farming as sustainable and therefore a panacea to the incessant food insecurity quagmire bedeviling drought prone regions like Chivi south. Such a scenario however puts the NGOs in question at crossroads concerning the question about whose interests they are championing through conservation farming. In principle they purport to embody the interests of the locals who are conceived as the real owners of the project but in reality it was observed that they are advancing their own interests and those of the Donor under the costume of participatory development and sustainable Agriculture. Consequently the facilitators of conservation farming have plunged it into a state of conflict and contradictions since the local farmers are now perceiving it as Care International or Action Faim's project rather than their program, as such the majority is doing everything within its capacity to derail the project, bringing confusion and uncertainty concerning the future of the program.

The situation in Chivi south reveals that in as much as the said NGOs are intending to move away from the dominant approaches to development, the legacy of these approaches is still haunting them. They have unwittingly reverted to the orthodox approach such as Modernization theory, where beneficiaries of development are viewed as ignorant and apathetic. What is at stake in Chivi south are contestations over whose episteme or knowledge should take precedence in conservation farming between the outsiders and the locals? Idyllically given the fact that participatory development is at stake the voice or knowledge of the beneficiaries of development should inform conservation farming. On the contrary the NGOs or the so called experts, principal in the marshaling of conservation farming, by virtue of them being the commanders of material resources which are translating into power. Owing to this predicament power straggles and contestations became inevitable since the locals are refusing to give into the whims and caprices of the NGOs. To this end, it can be argued that achieving sustainable livelihoods and sustainable development is not a deterministic affair; contestations, negotiations and trade-offs are evident at every turn.

The foregoing stance is in tandem with Foucault's position concerning power and knowledge in development discourse and practice. He posits that there is what is hitherto considered to be subjugated knowledge, subjugated because it is not supported by centers of power. Conversely the NGOs on the forefront of conservation farming are the centers of power since they are easily translating their material resources into power and by extension knowledge. Thus through power and ownership of material resources such as seed and fertilizers these NGOs are already creating hegemonic relations which are however divergent to the goals of participatory development and ultimately sustainable development. Of note however is the fact that the villagers in Chivi south as argued elsewhere in this paper are not sponges of development, hence they do not take what the NGOs have to offer at face value. As observed by Giddens (1985), the villagers in question are not passive recipients of development, rather they are knowledgeable, calculative and rational actors with the capacity to define and redefine conservation farming until it is acceptable to them. Therefore in as much as the NGOs are trying to create a hegemony over the villagers of Chivi south, through manipulation, these villagers embark on Counter hegemonic struggles, where they try to affirm and reaffirm their position and knowledge, thereby turning conservation farming into a political arena. These struggles take different forms. (The many ways in which the villagers respond to such a position will be dealt with in later sections). In contrast, other NGOs, especially those concerned with the environment have portrayed conservation farming as ecologically damaging due to excessive use of chemicals and pesticides instead of weeding and using organic manure. It should be noted that NGOs unwittingly assume that conservation farming is the desirable type of farming especially in drought prone regions and thus should be adopted to arrest the food insecurity catastrophe of these said areas. This stance however sowed seeds for community discontentment against the program. While aid 
organizations like ACTION FAIM advocate conservation farming as ideal for Chivi South, villagers in the area tended to view it as an imposition of the highly alien and impoverished form of farming, backbreaking, lacking relevance and draining on labour. Village farmers traditionally understood that ploughing the fields is essential to successful farming, albeit insistence by NGOs that conservation farming entails zero or at least minimum tillage of the land .This confirms findings made by Hobbs (2007) that many principles of conservation farming are radically different from conventional crop production practices. To this end, the researchers contend that such contrasting life-worlds have brought an impasse between local villagers and NGOs advocating conservation farming. This gives credence to Peluso \& Watts (2001) who argued that this portrays a typical example of a development impasse where powerful actors intent on creating in villagers a certain kind of 'development', forcing their ideas on their intended targets even if those targets define 'development' in completely different ways. It is against this background that Gukurume et al (2010) noted that what has been occurring in conservation farming projects is a chasm far more fundamental than just conflicting interests and life-worlds on what constitutes an ideal farming practice, rather it is a struggle to define what is "ideal knowledge". More so, it emerged that villagers have chronically insisted that conservation farming is more labour intensive and hence cannot work in Chivi South, an areas where the most productive age groups are migrating down south, yet NGOs are determined to make conservation farming work under such conditions for them to impress their donors and get more funding for the project. It is against this milieu that the researchers contend that the success of this program hinges on extensive enlightening and education in order to convince the villagers that conservation farming is a beneficial switch. This position is also echoed by Anderson (1992) and Hove \&Twomlow (2006) who noted that the success of conservation farming depends more on attitude, knowledge and precise management than it does on high levels of external inputs.

Local authorities and the politics of co-optation. From the outset it ought to be noted that the macro political relations between the civil society and the state is cascading down to the micro relations between the NGOs facilitating conservation farming and the local authorities in Chivi South. It should also be noted that the state com Zanu PF is creating a patron-client relationship with local leadership such as chiefs, headmen and village heads to the extent that these leaders have since become the custodians of the political interests of the former ruling party. The relations between the said actors can be analyzed through a bifurcated analysis that is relations of mistrust and co-optation. It emerged that during the initial stages of conservation farming the majority of local leaders, who are the gatekeepers in rural development, were highly skeptical about the agenda and objectives of these NGOs. This suspicion stems from the deeply entrenched conviction that the civil society in Zimbabwe is championing the interests of the opposition party and by extension the former British colonizers. The contentious nature of the land and land reform question in Zimbabwe is further compounding the already volatile situation, thereby jeopardizing the whole conservation farming program. Some of the development workers who were interviewed in this research narrated their ordeal in the initial attempt to penetrate the area in question, in order to facilitate conservation farming. In some cases local leadership is said to have mobilized gangs of youths to attack them on the pretext that they wanted to undermine the gains of the land reforms as well as the ruling party ideology. These local leaders paradoxically made a summersault decision with regards to how they perceived the program. They have since hijacked the program and are doing everything possible to co-opt the NGOs in their quest to gunner support for Zanu PF, concurrently gaining political mileage. The result is an ambivalent relationship, since the goals and interests of the NGOs operating in Chivi south are not in tandem with those of the local leadership. Some of the local leaders interviewed highlighted that they cannot tolerate outsiders telling them what is good for them because they are the masters of their own destiny. To this end, the researchers observed that some local leaders have simply accepted conservation farming in principle with the goal of accessing inputs and other benefits yet in reality they resent its prescriptions. It should thus be underscored that conservation farming and development in general as it is conceived by powerful actors wielding grand ideas about conservation farming, not only fails to boost agricultural production but actually chains local villagers to impoverished lives. Local leaders 
stressed that minimum tillage emphasized by NGOs cannot work in hot weather and dry regions since crops will easily wilt and this inevitably plunges them further into abject poverty and chronic food crisis. It is against this background that the contestations between local leaders and NGOs in the said area are so entrenched that an interface analysis becomes ideal for the sake of making this program a success. To this end, instead of ameliorating the challenges facing Chivi South, villagers and local leaders contend that conservation farming has in fact exacerbated these problems. From key informant interviews with local leadership, the researchers observed deep - seated tension and mistrust in the perceptions of the local leaders on conservation farming and NGO programmes in general as well as how these programmes are being implemented.

Extension workers' Positionality in the Conservation farming Project in Chivi. Extension workers operating in Chivi south are arguably the most strategic social actors in the conservation farming practice. They are powerful and influential because they have support from the government since they represent state agencies just like the local leaders. These social actors' position has been further reinforced by the volatile political environment obtaining in Zimbabwe and many times they have been manipulated by the former ruling party to champion its interests. Inasmuch as these extension workers are professionals, the majority of them have been forced to give into the demands of Zanu PF. Thus, their interests concerning conservation faming overlap with those of the politicians within Zanu PF. It was revealed that any extension worker seen not to advance the interests of the party endangers his carrier and life. It is interesting to note that one of the extension workers operating in Chivi south was fired and expelled from the area for having attended the opposition rally. These extension workers are however rational and calculative actors, thus they tended to vacillate in terms of positions and interest pertaining conservation farming. It was revealed that these social actors clandestinely support and get incentives from the NGOs facilitating conservation farming. This leaves these social actors at an 'intercalary' position where on one hand they have to represent the interests of the state and on the other hand their own interests in order to continue receiving incentives and gifts from the NGOs who are desperate to realize the fruits of the program. It should also be underscored that by virtue of their agricultural training, extension workers portray themselves as knowledgeable and hence better placed to heavily instruct not only NGOs but also local villagers on the "Nitti gritties" of conservation farming, while at the same time villagers stress that despite their training extension workers' knowledge of the local cosmology pertaining to climatic conditions are insignificant. To this end the researchers observed that there are protracted contestations on who is better placed to lead the conservation farming program. This is worsened by the fact that NGOs as the donors of the project also want to be heavily involved in the program to make it work. Moreso, local politicians have also demanded a stake in the program and at worst have hijacked the program as an attempt to gain political mileage. It is against this background that the researchers contend that the conservation farming program is embroiled in deep - seated contestation pitting several stakeholders involved in the program. It is such clash of interests and contestations that largely derail the positive outcomes of conservation farming (Gukurume et al, 2010; Ryan \&Spencer, 2001; Hobbs, 2007).Findings in this study portray that extension workers operating in the said area are sometimes at loggerheads with NGOs who more often than not impose certain ideologies on the villagers. It should be underscored that relationships between various stakeholders in the conservation farming program are characterized by suspicion, conflict and cooperation.

Ordinary villagers in Chivi south: Whose Knowledge counts? This category is the most spirited and vocal group though they are often sidelined in the development program formulation and implementation process. They were perceived by NGOs as pathetic, ignorant, conforming and helpless lot (Gukurume, Nhodo \& Dube, 2010) .Contrary to this deeply entrenched position this study reveals that the local villagers have the capability to use the power of the weak which is invariably forcing the NGOs to modify their rigid attitude towards the villagers in relation to conservation farming. The locals maintain that they ought to be the real owners of the conservation farming practice rather that operating according to the will of the NGOs who are prescribing conservation farming. To this end the villagers in question in relation to conservation farming are saying, "nothing for us without us". Although 
they are not openly showing their detest of the top-down approach used by NGOs in the said program, they are acting in various ways that will eventually reveal their position with regards to the farming Method. Through the use of a people centered methodology it was observed that the dwellers of Chivi south district are habitually showing the proponents of conservation farming their dislike of it through the use of the power of the weak or what Scott (1985) terms the everyday forms of resistance. These actions range from absenteeism with regards to meetings, pilfering, foot dragging and at times sabotaging the program by taking the inputs and reverting to the conventional ways of farming. This position is captured by the statement made by one of the respondents in this study who said; "diggaudyemahumbwechaiwo kana kutikutunganakwembudzi" ("Conservation farming is a waste of time and resources"). Different perceptions and conflicting life-worlds in conservation farming can also be seen between those who are participating in the program and those who have snubbed the program. The Non participants argued that rather than ameliorating food insecurity quagmires bedeviling their area, conservation farming has actually compounded food insecurity. This is primarily because despite getting seed and fertilizers, in terms of output, conservation farming falls way below the traditional or conventional farming methods which are tried and tested. They strongly argued that it is far much better to use the acquired seed for food rather than throwing the precious commodity down the drain. One respondent noted that villagers hate it when NGOs come and impose on them what to do, they simply want to be given inputs and then use these by themselves because they trust their methods to get the farming going more than these new and alien farming methods brought by NGOs. Farmers are thus suspicious of these new farming methods which are brought by outsiders who lack in-depth experience with the local conditions and priorities. The villagers are also shunning conservation farming because to them it is time consuming and labour intensive, a factor which does not go well with the particularities of Chivi south district which has been affected by the incessant labour migration to neighboring South Africa. This is in total contradiction with the view held by the proponents of conservation farming who argue that it is less Labour intensive compared to the traditional farming methods.

The aforementioned challenge has been aggravated by the fact that Chivi south district is closer to South Africa, thus they able bodied men and women have flocked down south leaving the young and the elderly to bear the brand of conservation mantra (see, Gukurume, Nhodo\& Dube, 2010). The researchers observed that villagers were torn between wanting to access the inputs from NGOs by partaking in conservation farming and fully implementing the prescriptions of conservation farming which most of them view as rather disastrous. This was because the multivalent and unpredictable outcomes of conservation farming made it an uncertain program for villagers. It should be underscored that the clash and contestations between the stakeholders involved in conservation farming are intimately linked to the incommensurable perspectives of the perceived benefits of the program and the actual outcomes of conservation farming. Villagers assert that conservation farming does not warrant the much heralded hype it is given, while NGOs stress that conservation farming is the panacea to a plethora of livelihood challenges confronting the villagers as alluded to earlier in the paper. The researchers noted that the dire need for inputs means that villagers 'cosmetically' or artificially participate in conservation farming project, albeit grudgingly if not under duress. This gives credence to Hobbs (2007) who noted that more often than not villagers are preoccupied with the issue of inputs, hence this significantly affect the long term success and sustainability of the conservation farming program. This position was also affirmed by Gukurume etal (2010) who argued that experience has shown that many peasant farmers join the conservation farming program purely to access inputs and other benefits and nothing else. It also emerged in interviews that after getting inputs some of the villagers in turn sell them to obtain cash for other livelihood needs; hence it can be argued that the input incentive is the main motivator behind villagers' participation in conservation farming rather than genuine commitment to the program. Observations made and findings in this study obliterate conclusions made by Hove \& Twomlow (2006) who argued that the majority of smallholder farmers in southern Africa struggle to cultivate their fields in a timely manner due to a lack of draft power. In contrast most villagers in Chivi contested the logic of having to dig basins when they have draft animals like donkeys and cattle. 
Reconciling the conflicting life-worlds for sustainable agriculture. To break the fore going impasse and salvage conservation farming from its doldrums, an interface analysis becomes a pre-requisite. As argued elsewhere in this paper an interface occurs at points where different, conflicting life-worlds or social fields occur or more concretely in situations or arenas in which interventions become oriented around problems of bridging, accommodating, segregating, or contesting social evaluative and cognitive standpoints towards any developmental intervention program. (See Long 1992).It emerged in this study that pseudo participation by local farmers in conservation farming is derived from the deeply entrenched conviction that conservation farming is an alien project that does not have a place in the development of the district in question(See Gukurume et al 2010). To remedy the situation, it is therefore imperative for Care International and Action Faim to cede power in favor of the local farmers or what Chambers says "putting the last first." This entails adopting genuine participation as opposed to passive participation, where the locals participate in the formulation, implementation and evaluation of the whole project. Such an approach will inevitably help to instill a sense of ownership of the program on the part of local farmers. This position is also in tandem with the observation made Salman (1987), who argued that beneficiaries of development in most cases participate and accept it when they appreciate and understand how the project may help them. Active participation as opposed to passive participation empowers the local farmers to mobilize their own capacities, be social actors rather than objects of development. Thus this type of participation helps to ensure the likelihood of conservation farming's sustainability in as much as it ensures acceptability by the farmers in question (see Gukurume et al 2010). Coupled with the need for active participation is the imperative of readdressing the issue of knowledge that informs conservation farming. Whereas the knowledge that is dominant in the said district is modern scientific knowledge and this type of knowledge as observed is coalescing against the realization of the gains of conservation farming. It is however prudent to argue that inasmuch as embracing Indigenous Knowledge is desirable, it is not feasible to completely jettison Modern Scientific knowledge because this type of knowledge has become a niche in rural development and it is also popular with donor agencies. Given this background, we therefore argue that there is need to triangulate or more appropriately interface the two types of episteme for conservation farming to have a bearing in Chivi south district.

In line with the foregoing argument it is also imperative for the exponents of conservation farming to engage in rigorous conscientisation of local farmers on the significance of the program as a livelihood strategy, aimed at ameliorate the food insecurity quandary they are facing. This is primarily because this study exposes consultation deficiency on the part of the NGOs operating in the area. In as much as this approach may entail the reversal of the piecemeal gains made thus far, it remains indispensible for conservation farming to have meaning and achieve its much vaunted objectives. This position is further buttressed by the fact that the "cosmetic" participation stems from the fact that local farmers as rational actors see other benefits from conservation farming, such as seed, fertilizers and other farming implements rather than genuine desire to partake in conservation farming.

The above mentioned approach will ultimately go a long way in changing the negative perceptions and attitudes held by the local farmers. This conscientisation should not only be limited to local farmers but should also be extended to local leadership, politicians and extension workers, since it was observed that just like the local farmers these categories do not understand the meaning of this farming practice.

\section{CONLUSION}

Conservation farming as exposed in this study is marred by conflicts of interest between various stakeholders ranging from the local farmers themselves, the NGOs, local leadership, extension workers inter alia. The NGOs as revealed have a vested interest in the continuity and sustainability of the said farming practice, with the main objective being to keep on receiving the much need funding from the donor community. These NGOs are purporting to take a people centered development, through participatory development on 
paper but in reality this treatise exposed the flaws associated with the method since the NGOs have reverted to orthodox developmental approaches, which are top down in nature. The local farmers by virtue of them being rational, calculative and powerful social actors have refused to be sponges of development. Thus they are engaging in counter-hegemonic struggles where, they seek to reassert and reclaim the lost voice in development. It was also revealed that the interests of these strategic social actors are at variance with those of the NGOs. The local smallholder farmers are therefore trying to smuggle their interests in conservation farming and this is coalescing against the success of the farming intervention program. The delicate situation has been further compounded by the interests of other social actors such as local authorities, extension workers and politicians who have refused to be left out in the battle for ownership of conservation farming. Their interests are at loggerheads with those of the NGOs and smallholder farmers and this ambivalence is inexorably having negative ramifications on the overall success of conservation farming. Thus it is contrary to the goals and ideals of sustainable development. Given this scenario an interface analysis has been recommended as a panacea to this conservation farming juggernaut since it helps to reconcile the said conflicts and contradictions embedded in this farming method. Taking Chivi south district as our focal point we therefore argued that sustainable development will remain precarious as long as conservation farming is deficient in grassroots support.

\section{REFERENCES}

[1] Anderson, J.R. (1992). Difficulties in African agricultural systems enhancement? Ten hypotheses. Agricultural Systems 38:387-409.

[2] Derpsch, R. (2008) Global overview of Conservation Agriculture adoption.Invited Paper, 4th World Congress on Conservation Agriculture: Innovations for Improving Efficiency, Equity and Environment, 4-7 February. New Delhi: ICAR. On http://www.fao.org/ag/ca.

[3] FAO (2008) Investing in Sustainable Crop Intensification: The Case for Soil Health. Report of the International Technical Workshop, FAO, Rome, July. Integrated Crop Management, Vol. 6. Rome: FAO. On http://www.fao.org/ag/ca/.

[4] Giddens, A. (1985). Constitution of Society, Cambridge polity press Oxford.

[5] Growing, J.W. \& Palmer, M. (2008).Sustainable agricultural development in subSaharan Africa: the case for a paradigm shift in land husbandry. Soil Use Management 24, 92-99.

[6] Fowler, R. \&Rockstrom, J. (2001) Conservation tillage for sustainable agriculture: an agrarian revolution gathers momentum in Africa. Soil \& Tillage Research 61, 93-107.

[7] Friedrich, T. \&Kassam, A.H. (2009).Adoption of Conservation Agriculture technologies: constraints and opportunities. Invited paper, 4th World Congress on Conservation Agriculture, 4-7 February. New Delhi: ICAR.

[8] Haggblade, S \&Tembo, G. (2003).Conservation farming in Zambia. Presented at the In WENT, IFPRI, NEPAD, CTA conference Successes in African Agriculture, Pretoria, December 1-3, 2003.

[9] Hobbs, P.R. (2007) Conservation agriculture: what is it and why is it important for future sustainable food production? Journal of Agricultural Science 145, 127-137.

[10] Hobbs, P.R., Sayre, K. \& Gupta, R. (2008). The role of conservation agriculture in sustainable agriculture.Philosophical Transactions of the Royal Society B 363, 543555.

[11] Kassam, A.H. (2009). Rethinking agriculture. Agriculture for Development 1 (Spring), 29-32. Rothes, UK: Tropical Agriculture Association.

[12] Khamphorst, D.Koopmanschap, N\&Oudwater, N. (2009).Effective Participation in Wildlife Management in Zimbabwe's CAMPFIRE Programme. The Journal of Agricultural Education and Extension, 4(3) pp 173 - 189.Routledge.

[13] Kaumbutho, P. \&Kienzle, J. (Eds) (2008).Conservation Agriculture as Practiced in Kenya: Two Case Studies. Rome: FAO.

[14] Lahmar, R. (2009). Adoption of conservation agriculture in Europe: lessons of the KASSA project. Land Use Policy 27 (1), 4-10. doi:10.1016/j.landusepol.2008.02.001. 
[15] Landers, J. (2007). Tropical Crop-Livestock Systems in Conservation Agriculture: The Brazilian Experience. Integrated Crop Management, Vol. 5. Rome: FAO.

[16] Long, N. (1992).The Multiple Optic of Interface Analysis.Wageningen: Wageningen University, Nertherlands.

[17] Mazvimavi, K. \&Twomlow, S. (2008). Conservation farming for agricultural relief and development in Zimbabwe. In: T. Goddard, M.A. Zoebisch, Y.T. Gan, W. Ellis, A. Watson and S. Sombatpanit (eds) No-Till Farming Systems. Special Publication No. 3 (pp. 169-175). Bangkok: World Association of Soil and Water Conservation (WASWC).

[18] Makwara, E.C. (2010).Sustainable and Profitable Farming through Conservation Agriculture in Zimbabwe: Prospects, Opportunities and Constraints. Journal of Sustainable Development in Africa, Vol 12 (8) pp 180 - 190.

[19] Peluso, N.L. \& M.J. Watts (2001).Violent Environments. In Violent Environments, eds. N.L. Peluso and M. Watts, 3-38. Ithaca: Cornell University Press.

[20] Ryan, J.G \& Spencer, D.C. (2001). Future challenges and opportunities for agricultural R\&D in the semi-arid tropics. Patancheru 502 324, India: ICRISAT.

[21] Scott, J. (1985). Weapons of the weak, everyday forms of peasant resistance: New haven. Chicago: Yale University Press.

[22] Simuyemba, J. (1998). Minimum tillage comparative trial results. A study report.

[23] Stoop, W.A. \&Kassam, A.H. (2005). The SRI controversy: a response. Field Crops Research 91, 357-360.

[24] Shaxson, T.F. (2006). Re-thinking the conservation of carbon, water and soil: a different perspective. Agronomie 26, 1-9.

[25] Shiferaw, B \&Bantilan, C. (2004). Rural poverty and natural resource management in less-favored areas: Revisiting challenges and conceptual issues. Journal of Food, Agriculture and Environment 2:328-339.

[26] Uphoff, N. \&Kassam, A.H. (2009) System of Rice Intensification (SRI).Agriculture for Developing Countries. Science and Technology Options Assessment (STOA) Project. Karlsruhe, Germany: European Technology Assessment Group. 